\title{
HUBUNGAN ANTARA DISIPLIN KERJA DAN MOTIVASI BERPRESTASI DENGAN KINERJA GURU SEKOLAH MENENGAH PERTAMA (SMP) NEGERI DI KECAMATAN BUKIT RAYA KOTA PEKANBARU
}

\author{
Reni Despari ${ }^{1)}$ \\ Isjoni ${ }^{2)}$ \\ Azhar 3) \\ 1) SMK Manajemen Penerbangan Pekanbaru \\ 2) Lecturer of Education Management Study Programme PPS University of Riau \\ ${ }^{3)}$ Lecturer of Education Management Study Programme PPS University of Riau \\ E-mail: renidespari89@gmail.com
}

\begin{abstract}
The purpose of this study was to analyze the correllation between work discipline and achievement motivation with the teachers performance of junior high school (SMP) in Bukit Raya sub-district, Pekanbaru City. The population and sample from this study were junior high school teachers who were in Bukit Raya sub-district, Pekanbaru City, totalling 60 people and all were studied. This research method uses the questionnaire method (questionnaire). The type of data from this study is primary data sourced from the junior high school (SMP) teachers in Bukit Raya sub-district, Pekanbaru City. The data analysis technique used in this study uses descriptive and inferential statistics. Data analysis method in this research uses multiple regression. The results showed that work discipline and achievement motivation had a positive correlation with teacher performance both simultaneously and partially.
\end{abstract}

Keywords: Work Discipline; Achievement Motivation; Teacher Performance

\begin{abstract}
ABSTRAK
Tujuan penelitian ini adalah untuk menganalisis hubungan antara disiplin kerja dan motivasi berprestasi dengan kinerja guru Sekolah Menengah Pertama (SMP) Negeri di Kecamatan Bukit Raya Kota Pekanbaru. Populasi dan sampel dari penelitian ini adalah guru SMP Negeri yang berada di Kecamatan Bukit Raya Kota Pekanbaru yang berjumlah 60 orang dan semua diteliti. Metode penelitian ini menggunakan metode kuisioner (angket). Jenis data dari penelitian ini adalah data primer yang bersumber dari guru SMP Negeri di Kecamatan Bukit Raya Kota Pekanbaru. Teknis analisis data yang dilakukan dalam penelitian ini menggunakan statistik deskriptif maupun inferensial. Metode analisis data dalam penelitian ini menggunakan regresi berganda. Hasil penelitian menunjukkan bahwa disiplin kerja dan motivasi berprestasi memiliki hubungan positif dengan kinerja guru baik secara simultan maupun secara parsial.
\end{abstract}

Kata Kunci: Disiplin Kerja, Motivasi Berprestasi, Kinerja Guru 


\section{PENDAHULUAN}

Pendidikan Nasional bertujuan mencerdaskan kehidupan bangsa dan mengembangkan manusia Indonesia seutuhnya oleh karena itu sangat dibutuhkan profesionalisme para pendidik (guru-guru), sebagaimana disebutkan dalam Undang-Undang Republik Indonesia Nomor 20 Tahun 2003 tentang Sistem Pendidikan Nasional, bahwa jabatan guru sebagai pendidik merupakan jabatan profesional.

Kedisiplinan kerja guru penting untuk diperhatikan karena keberhasilan pendidikan banyak berharap dari guru. Kinerja guru yang baik tidak dapat dicapai jika tidak disertai dengan ketaatan guru pada peraturan-peraturan yang berlaku dalam melaksanakan pekerjaan. Menjunjung tinggi kedisiplinan juga dapat menjadikan pandangan masyarakat lebih baik sehingga kepercayaan masyarakat terhadap sekolah tersebut dapat meningkat.

Simamora (2004) menyatakan bahwa "motivasi adalah dorongan psikologis yang mengarahkan seseorang menuju sebuah tujuan. Semakin karyawan diberikan motivasi sesuai dengan kebutuhannya, maka kinerja pegawai yang bersangkutan dapat ditingkatkan. Apabila guru diberi motivasi namun tidak sesuai dengan kebutuhannya, maka pemberian motivasi akan berlangsung sia-sia tanpa hasil.

Berdasarkan hasil pengamatan penulis pada SMP Negeri di Kecamatan Bukit Raya Kota Pekanbaru ditemukan beberapa masalah antara lain adalah (1) masih banyak guru yang belum melaksanakan penelitian tindakan kelas menyebabkan guru kurang mengetahui kekurangan yang terjadi dalam proses pembelajaran untuk selanjutnya diadakan perbaikan, (2) keterbatasan media pembelajaran dan penggunaan metode ceramah yang dominan membuat proses pembelajaran menjadi kurang variatif, (3) masih ada guru kurang mengomunikasikan bahan pengajaran dengan baik, sehingga siswa sulit menerima dan memahami materi, (4) guru dalam mengembangkan RPP biasanya masih menggunakan perangkat tahun lalu dengan mengganti tahun selanjutnya, (5) menjelaskan materi terlalu cepat, dan (6) masih ada guru yang mengajar hanya memberikan tugas setelah itu hanya ditinggalkan begitu saja tanpa diawasi, dan (7) Ada guru yang mengajar tidak relevan dengan bidangnya.

Selain itu terdapat masalah lain yang dihadapi yaitu kurangnya disiplin kerja guru dalam hal ketepatan jam pelajaran. Setiap guru rata-rata tiga kali datang terlambat ke sekolah dalam seminggu sehingga menimbulkan situasi yang kurang mendukung dalam proses pembelajaran dan kesadaran guru mengenai arti penting disiplin kerja dalam melaksanakan tugas tugasnya juga masih rendah. Masalah ini timbul karena masih ada guru baru atau berusia muda yang meniru kebiasaan tidak disiplin yang dilakukan oleh guru yang telah lebih lama mengajar.

Kebiasaan tidak baik seperti ini apabila sering dilakukan dapat mengganggu proses belajar mengajar dan secara otomatis menjadi contoh yang tidak baik pula bagi para siswa. Peraturan yang ada di sekolah juga belum optimal dalam mengatasi pelanggaran kedisiplinan karena kurangnya ketegasan dari kepala sekolah dalam menindaklanjuti pelanggaran yang terjadi. Masalah lain yang timbul adalah guru masih kurang terpacu dan termotivasi dalam memberdayakan dirinya untuk potensi kreativitasnya. Padahal apabila para 
guru memiliki kemauan dan bersedia memaksimalkan potensi kreativitasnya dapat memberikan pengaruh yang baik juga terhadap kinerjanya dan peningkatan karirnya.

Kinerja dipengaruhi oleh beberapa faktor yaitu kemampuan guru, motivasi, dan disiplin kerja. Sehingga jika motivasi dan disiplin ditingkatkan maka kinerja guru juga akan meningkat begitu juga sebaliknya.

Melihat pengamatan di lapangan ,maka penulis termotivasi untuk melakukan penelitian tentang disiplin kerja dan motivasi berprestasi guru pada SMP Negeri di Kecamatan Bukitraya Kota Pekanbaru dengan judul "Hubungan antara disiplin kerja dan motivasi berprestasi dengan kinerja guru Sekolah Menengah Pertama (SMP) Negeri di Kecamatan Bukit Raya Kota Pekanbaru".

Adapun rumusan masalah penelitian dapat dirumuskan sebagai berikut:

1. Apakah terdapat hubungan antara disiplin kerja dengan kinerja guru Sekolah Menengah Pertama (SMP) Negeri di Kecamatan Bukit Raya Pekanbaru?

2. Apakah terdapat hubungan antara motivasi berprestasi dengan kinerja guru Sekolah Menengah Pertama (SMP) Negeri di Kecamatan Bukit Raya Pekanbaru?

3. Apakah teradapat hubungan antara disiplin kerja dan motivasi berprestasi secara bersama-sama dengan kinerja guru Sekolah Menengah Pertama (SMP) Negeri di Kecamatan Bukit raya Pekanbaru?

Menurut Sugiyono (2006:10), dalam paradigma terdapat dua variabel independen dan satu dependen. Dalam paradigma ini terdapat 3 rumusan masalah deskriptif dan 4 rumusan asosiatif (3 korelasi sederhana dan 1 korelasi ganda).

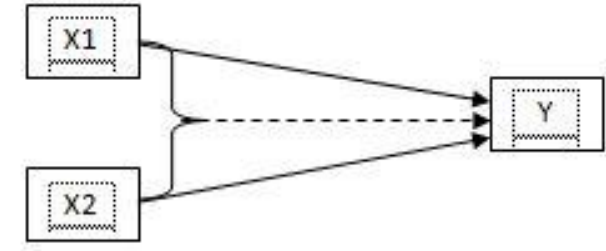

X1 : variabel Disiplin Kerja

X2 : variabel Motivasi Berprestasi

Y : variabel Kinerja Guru

$\longrightarrow \quad$ : Hubungan antara Disiplin Kerja dan Motivasi Berprestasi Dengan Kinerja guru secara sendiri-sendiri

$\ldots \quad$ : Hubungan antara Disiplin Kerja dan Motivasi

Berprestasi Dengan Kinerja guru secara bersama-sama

Dari deskripsi teoretis ketiga variabel dan kerangka berpikir diatas maka dapat ditarik hipotesis penelitian sebagai berikut:

1. Terdapat hubungan positif antara disiplin kerja dengan kinerja guru Sekolah Menengah Pertama (SMP) Negeri di Kecamatan Bukit Raya Pekanbaru

2. Terdapat hubungan positif antara motivasi berprestasi dengan kinerja guru Sekolah Menengah Pertama (SMP) Negeri di Kecamatan Bukit Raya Pekanbaru

3. Terdapat hubungan positif antara disiplin kerja dan motivasi berprestasi secara bersama-sama dengan kinerja guru Sekolah Menengah Pertama (SMP) Negeri di Kecamatan Bukit Raya Pekanbaru

\section{METODOLOGI PENELITIAN}

Penelitian ini dilakukan pada Sekolah Menengah Pertama (SMP) Negeri di Kecamatan Bukit Raya Pekanbaru.

Populasi dalam penelitian ini adalah Guru pada Sekolah Menengah Pertama (SMP) Negeri di Kecamatan Bukit Raya Pekanbaru, dengan jumlah 71 orang. 
Berdasarkan rumus yang digunakan maka didapati sampel sebanyak 60 orang guru Sekolah Menengah Pertama (SMP) Negeri di Kecamatan Bukit Raya Pekanbaru.

\begin{tabular}{|c|c|c|c|}
\hline \multirow{2}{*}{ № } & \multirow{2}{*}{ Nama Sekolah } & \multicolumn{2}{|c|}{ Jumlah Guru } \\
\hline & & Populasi & Sampel \\
\hline 1 & SMP Negeri 22 Pekanbaru & 40 Orang & 34 Orang \\
\hline 2 & SMP Negeri 35 Pekanbaru & 31 Orang & 26 Orang \\
\hline & Jumlah & 71 Orang & 60 Orang \\
\hline
\end{tabular}

Teknik pengumpulan data yang digunakan adalah menggunakan kuesioner (angket) untuk semua variabel.

Untuk instrumen penelitian yang digunakan pada masing-masing variabel telah valid dan reliabel yang telah diuji oleh peneliti sebelumnya.

Kisi-kisi instrumen penelitian pada penelitian ini yakni:

a. Variabel Disiplin Kerja (X1)

Indikatornya : Ketepatan waktu, ketaatan terhadap peraturan, tanggung jawab kerja dan melaksanakan tugas dan kewajiban

b. Variabel Motivasi Berprestasi (X2) Indikatornya: Need for Achieve ment, Need for affiliation dan Need For Power

c. Variabel Kinerja Kerja (Y)

Indikatornya : Kinerja guru dalam merencanakan proses belajar mengajar, kinerja guru dalam pelaksanaan pembelajaran, kinerja guru dalam evaluasi tugas dan kinerja guru dalam disiplin tugas

Setiap jawaban dihubungkan dengan bentuk pernyataan atau dukungan sikap yang diungkapkan dengan kata-kata sebagai berikut:

\section{$\underline{\text { Pernyataan Positif }}$}

a. Skor 5 jika jawaban responden sangat sering

b. Skor 4 jika jawaban responden sering

c. Skor 3 jika jawaban responden kadang-kadang

d. Skor 2 jika jawaban responden kurang

e. Skor 1 jika jawaban responden tidak pernah

\section{Pernyataan Negatif}

a. Skor 5 jika jawaban responden tidak pernah

b. Skor 4 jika jawaban responden kurang

c. Skor 3 jika jawaban responden kadang-kadang

d. Skor 2 jika jawaban responden sering

e. Skor 1 jika jawaban responden sangat sering

Teknis analisis data yang dilakukan dalam penelitian ini menggunakan statistik deskriptif maupun inferensial. Analisis deskriptif yang digunakan dalam bentuk: 1) penyajian data meliputi daftar distribusi dan histogram; 2) ukuran sentral meliputi mean, median, dan modus; 3) ukuran penyebaran meliputi varians dan standar deviasi. Analisis inferensial digunakan untuk menguji hipotesis dengan menggunakan analisis regresi yang di dahului dengan: 1) Uji normalitas dengan menggunakan uji Kolmogorov_smirnov; 2) uji signifikansi dan linearitas regresi dengan menggunakan uji $\mathrm{t}$ dan uji $\mathrm{F}$ dalam perhitungan digunakan jasa komputer berupa software dengan program SPSS for Window Version 20

\section{HASIL PENELITIAN DAN PEMBAHASAN}

Dari hasil perhitungan diperoleh koefisien korelasi $(\mathrm{R})=0,851$ atau 85,1 $\%$. Ini berarti hubungan disiplin kerja 
dan motivasi berprestasi dengan kinerja guru secara simultan sebesar $85,1 \%$.

Terdapat hubungan Disiplin Kerja dengan kinerja guru. Dari perhitungan diperoleh Unstandardized Coefficients didapat hubungan disiplin kerja terhadap kinerja guru sebesar $(0,485)=$ $48,5 \%$. Artinya dalam penelitian ini Disiplin Kerja berhubungan dengan kinerja guru sebesar 48,5\%.

Terdapat hubungan Motivasi Berprestasi dengan kinerja guru. Dari perhitungan Unstandardized Coefficients didapat hubungan Motivasi Berprestasi dengan kinerja guru sebesar $(0,427)=42,7 \%$. Artinya dalam penelitian ini motivasi berprestasi berhubungan dengan kinerja guru sebesar $42,7 \%$.

Besar hubungan disiplin Kerja dan motivasi berprestasi dengan kinerja guru adalah 0,851 dan sisanya sebesar 0,149 (1-0,851) berhubungan dengan variabel lain yang tidak diteliti pada penelitian ini seperti, gaji atau upah serta tunjangan, hubungan antar pribadi dan promosi dan imbalan jasa serta banyak variabel lainnya. Seperti pendapat Danim (2012:18) dan Hasibuan (2014:149).

Hasil penelitian menunjukkan bahwa terdapat hubungan yang positif antara Disiplin Kerja dengan kinerja guru. Hasil ini dibuktikan dengan koefisien korelasi sebesar 0,485. Hasil penelitian ini sejalan dengan penelitian terdahulu yaitu penelitian Dwi (2017) yang menyatakan bahwa disiplin kerja berhubungan dengan kinerja guru.

Hasil penelitian menunjukkan bahwa terdapat hubungan yang positif antara Motivasi Berprestasi dengan kinerja guru. Hasil ini dibuktikan dengan koefisien korelasi sebesar 0,427. Hasil penelitian ini sejalan dengan penelitian terdahulu yaitu, penelitian Asmin (2017) dan Indrayogi (2014) yang menyatakan bahwa motivasi berprestasi berhubungan dengan kinerja guru

Berdasarkan penjelasan diatas dapat disimpulkan bahwa disiplin kerja dan motivasi berprestasi memiliki hubungan positif secara simultan dan signifikan terhadap kinerja guru.

\section{SIMPULAN}

Berdasarkan pengujian hipotesis dan pembahasan hasil penelitian, diperoleh kesimpulan:

1. Terdapat hubungan positif secara bersama-sama antara disiplin kerja dan motivasi berprestasi dengan Kinerja Guru Sekolah Menengah Pertama (SMP) Negeri di Kecamatan Bukit Raya Pekanbaru.

2. Terdapat hubungan positif disiplin kerja dengan Kinerja Guru Sekolah Menengah Pertama (SMP) Negeri di Kecamatan Bukit Raya Pekanbaru.

3. Terdapat hubungan positif motivasi berprestasi dengan Kinerja Guru Sekolah Menengah Pertama (SMP) Negeri di Kecamatan Bukit Raya Pekanbaru.

\section{Saran}

Berdasarkan beberapa simpulan yang telah dibuat rasanya perlu pada penelitian ini di kemukakan beberapa saran dalam rangka meningkatkan Kinerja Guru SMP Negeri di Kecamatan Bukit Raya Pekanbaru, saran-saran yang disampaikan berhubungan dengan temuan penelitian ini adalah sebagai berikut:

\section{Saran Praktis}

a. Pada variabel Disiplin Kerja yang diberikan sekolah sudah tinggi, akan tetapi untuk indikator ketaatan terhadap peraturan memiliki nilai yang rendah dibanding indikator yang lainnya. Dalam hal ini Kepala Sekolah dituntut untuk meningkatkan kedisiplinan guru dengan 
memberikan reward and punishment diartikan sebagai pemberian penghargaan dan hukuman, penghargaan disini bukan hanya penghargaan dalam bentuk materi akan tetapi termasuk di dalamnya adalah pujian kepada guru yang dipandang disiplin dalam menaati peraturan sekolah dan memberikan teguran atau hukuman kepada guru yang sering melanggar aturan seperti pemotongan tunjangan. Kepala Sekolah melakukan pendekatan personal, melalui komunikasi yang baik kepada para guru serta memberikan motivasi, kemudian memberikan kesempatan kepada guru untuk dapat menunjukkan kemampuannya jika diberikan tugas dan tanggung jawab agar selalu patuh terhadap aturan yang telah dibuat baik peraturan tertulis maupun tidak tertulisn dan Kepala Sekolah menjadi contoh keteladanan disiplin dalam sikap dan perilaku.

b. Pada Variabel Motivasi Berprestasi yang diberikan sekolah sudah tinggi, akan tetapi untuk indikator Need For Achievement (kebutuhan akan prestasi) memiliki nilai yang rendah dibandingkan indikator lainnya. Hal ini harus menjadi perhatian bagi Kepala Sekolah yang selalu dituntut untuk memberikan motivasi berprestasi kepada guru dalam meningkatkan kinerja guru, dengan memperhatikan kesejahteraan guru, memberikan pengakuan atau penghargaan dan menumbuhkan keinginan guru untuk berprestasi.

c. Pada Variabel Kinerja Guru yang diberikan sekolah sudah tinggi, akan tetapi untuk indikator kinerja guru dalam evaluasi pembelajaran masih rendah dibandingkan indikator lainnya. Dalam hal ini Kepala Sekolah agar Proaktif mendorong guru untuk mengikuti kegiatan pembinaan, penataran, seminar atau workshop yang berhubungan dengan evaluasi pembelajaran kepada guru.

\section{Saran Teoritis}

a. Menambahkan indikator atau variabel penelitian yang belum dimasukkan dalam model penelitian ini, baik yang mempengaruhi disiplin kerja, motivasi berprestasi dan kinerja guru di sekolah. Dengan demikian, hasil penelitian berikutnya dapat lebih sempurna dan kesimpulan yang diperoleh dapat berbeda atau tetap sama dengan hasil penelitian ini.

b. Keterbatasan dalam penelitian ini, peneliti menggunakan angket sebagai alat pengukuran variabel penelitian, peneliti tidak melakukan wawancara, sehingga kesimpulan yang diambil hanya berdasarkan pada data yang dikumpulkan melalui penggunaan instrumen secara tertulis. Jadi untuk peneliti selanjutnya supaya lebih memperluas alat ukur penelitian, sehingga hasil penelitian mampu memberikan daya generalisasi yang lebih baik.

\section{DAFTAR PUSTAKA}

Danim, Sudarwan, (2004). Motivasi Kepemimpinan \& Efektivitas Kelompok, Jakarta: Rineka Cipta.

Depdiknas, (2003). Undang-Undang No. 20 tahun 2003 tentang Sistem Pendidikan.

Depdiknas, (2005). Undang-Undang No. 14 tahun 2005 tentang Guru dan Dosen.

Djamarah S.B, (2000). Strategi Belajar Mengajar. Jakarta: Rineka Cipta 
Gumelar \& Dahyat, (2000). Manajemen Pendidikan. Jakarta: Rineka Cipta

Hamzah, (2007). Profesi Kependidikan. Jakarta : Bumi Aksara

Mulyasa, (2011). Menjadi guru profesional. Bandung : PT. Remaja Rosdakarya

Mulyasa, H, E. (2013). Uji Kompetensi dan Penilaian kinerja guru. Jakarta: Remaja Rosda Karya

Muhammad, Arni.(2015). Komunikasi Organisasi. Jakarta : Bumi Aksara

Mulyana, Deddy. (2005). Komunikasi Efektif, Suatu Pendekatan Lintas Budaya. Bandung: Alumni

Rakhmat, Jalaludin. (2008). Psikologi Komunikasi.Bandung:Remaja Rosda karya

Robins, Stephan P. (2015). Prilaku Organisasi. Salemba Empat. Jakarta

Shuck, Dale. (2012). Motivasi dalam Pendidikan. Indeks. Jakarta

Suprihatiningrum, Jamil. (2016). Guru Profesional. Jogjakarta : ArRuzz Media

Sondang P, Siagian. (2006). Manajemen Sumber Daya Manusia. Jakarta : Bumi Aksara

Sopiah. (2008) .Prilaku Organisasi. Andi Offset. Yogyakarta
Sugiyono. (2009). Statistika untuk penelitian. Bandung: CV. Alfabeta

Sutrisno, Edy. (2011). Budaya Organisasi. Indeks Kelompok Gramedia: Jakarta

Umar, Husen. (2008). Riset Sumber Daya Manusia dalam Organisasi. Jakarta: PT.Gramedia

Uno, Hamzah B. (2008). Teori Motivasi dan Pengukuran : Analisis Bidang Pendidikan. Jakarta : Bumi Aksara.

Wahjosumidjo. (2007). Kepemimpinan Kepala Sekolah. Jakarta : Raja Grafindo Persada

Wibowo. (2007). Manajemen Kinerja. Raja Grafindo Persada : Jakarta

Yunus. (2007). Interaksi dan Motivasi Belajar. Raja Grafindo Persada : Jakarta.

Fredianto, Didik. (2016). Hubungan antara Motivasi kerja dan Kedisiplinan dengan Kinerja Guru di SD Negeri 009 Kecamatan Batik Nau Kabupaten Bengkulu Utara. Jurnal Manajer Pendidikan. 10 (4), 354-361. 2016. https://ejournal.unib.ac.id/inde x.php/manajer pendidikan/article/view/1280/0

Indrayogi. (2015). Pengaruh Kompetensi dan Motivasi ber prestasi terhadap kinerja guru pendidikan jasmani SMP Negeri se-Kabupaten Majalengka. Jurnal Education FKIP UNMA Indonesia. 1 (1), 
63-85.

2015.

http://jurnal.unma.ac.id/index.p hp/edc/article /view/443/0

Supriyono, Asmin. (2017, September). Pengaruh Kompetensi pedagogik,profesional, dan motivasi kerja terhadap kinerja guru sekolah dasar. Jurnal Pendidikan Pascasarjana Universitas Terbuka.18 (02), 1-12. September, 2017. http://jurnal.ut.ac.id/ index.php/jp/article/view/269/2 $\underline{50}$

Sugiarti, Rita Retnowati, Eka Suhardi. (2018, Juli). Hubungan antara kompetensi profesional dan motivasi berprestasi dengan kreativitas kerja guru. Jurnal Manajemen Pendidikan. 6 (2), 683-691. Juli 2, 2018. https://journal.unpak.ac.id/inde x.php/JMP/article/view/795 